\title{
The effect of synaptic plasticity on the stability of place fields under graded environmental perturbations
}

\author{
Kathryn Ward ${ }^{1 *}$, Horatiu Voitu ${ }^{2}$, Steve Cox ${ }^{1}$, James Knierim³ ${ }^{3}$, Anthony Kellems ${ }^{1}$ \\ From Nineteenth Annual Computational Neuroscience Meeting: CNS*2010 \\ San Antonio, TX, USA. 24-30 July 2010
}

We developed a parallel computational model of a network of entorhinal and hippocampal cells influenced by synaptic plasticity to examine the stability of CA3 place fields under graded environmental perturbations. Place cells form single firing fields within an environment and are located in the CA1 and CA3 subregions of the hippocampus. They receive the majority of their spatial input from grid cells, which are located in the medial entorhinal cortex (MEC) and fire in hexagonal patterns within an environment [1].

We designed the model in the context of the "double rotation" experiment in which a rat circles a track with various local and distal cues that are rotated in opposite directions. In response to this rotation, some CA1 cells follow local cues, some follow distal cues, and some remap. In contrast, CA3 place fields are more coherently dominated by local cues [2]. This CA3 response is puzzling given that grid cells are more strongly controlled by distal cues [3]. Because local cues were rotated in a direction opposite to the rat's movement, the backward shift of place fields [4] may affect the CA3 response. Cells in the lateral entorhinal cortex (LEC) show a slight tendency to follow local cues [3], and we used the model to investigate whether the backward shift couples with weak LEC input to cause CA3 cells to rotate with the local cues.

In the model the MEC contains grid cells, and LEC cells are weakly tuned to local cues. CA1 and CA3 cells are governed by the integrate and fire model, which provides no bias for spiking at one location over another. Rate-based plasticity [5] applied to the connections from grid cells to hippocampal cells enables place fields to

\footnotetext{
* Correspondence: kw5@rice.edu

'Department of Computational and Applied Mathematics, Rice University, Houston, TX 77005, USA
}

form, and spike-timing-dependent plasticity [6] applied to the connections among CA3 cells enables place fields to shift backward, as seen experimentally.

We implemented the model in PETSc (Portable, Extensible Toolkit for Scientific Computation), a suite of data structures and routines for parallel computation. This implementation greatly increased both the number of tractable variables and the speed of computation. We simulated networks of up to 20,000 cells, and the computational time reduces by a factor of 15 as we move from one processor to 64 processors. Because the model is efficient, modular, and capable of simulating large networks, it is an efficient tool for examining the effect of synaptic plasticity on place field dynamics.

\section{Author details}

'Department of Computational and Applied Mathematics, Rice University, Houston, TX 77005, USA. ${ }^{2}$ Department of Neurobiology and Anatomy, University of Texas Medical School at Houston, Houston, TX 77030, USA. ${ }^{3}$ Department of Neuroscience and Krieger Mind/Brain Institute, Johns Hopkins University, Baltimore, MD 21218, USA.

Published: 20 July 2010

\section{References}

1. Hafting T, Fyhn M, Molden S, Moser M, Moser E: Microstructure of a spatial map in the entorhinal cortex. Nature 2005, 436:801-806.

2. Lee I, Yoganarasimha D, Rao G, Knierim J: Comparison of population coherence of place cells in hippocampal subfields CA1 and CA3. Nature 2004, 430:456-459.

3. Neunuebel J, Rao G, Yoganarasimha D, Knierim J: Differential control of lateral and medial entorhinal cortex by local and global cues. Program No. 100.4. 2009 Neuroscience Meeting Planner. Chicago, IL: Society of Neuroscience 2009, Online.

4. Mehta MR, Barnes CA, McNaughton BL: Experience-dependent, asymmetric expansion of hippocampal place fields. Proc Natl Acad SCi U S A 1997, 94:8918-8921. 
5. Savelli F, Knierim J: A Hebbian model of the formation of place fields from MEC grid inputs. Program No. 205.21. 2007 Neuroscience Meeting Planner. San Diego, CA: Society for Neuroscience 2007, Online.

6. Song $S$, Miller K, Abbott L: Competitive Hebbian learning through spiketiming-dependent synaptic plasticity. Nature Neuroscience 2000, 3:919-926.

doi:10.1186/1471-2202-11-S1-P102

Cite this article as: Ward et al.: The effect of synaptic plasticity on the stability of place fields under graded environmental perturbations. BMC Neuroscience 2010 11(Suppl 1):P102.

Submit your next manuscript to BioMed Central and take full advantage of:

- Convenient online submission

- Thorough peer review

- No space constraints or color figure charges

- Immediate publication on acceptance

- Inclusion in PubMed, CAS, Scopus and Google Scholar

- Research which is freely available for redistribution

Submit your manuscript at www.biomedcentral.com/submit
C Biomed Central 